https://doi.org/10.15407/dopovidi2021.06.087

УДК 550.348.334 (477.63)

О.В. Кендзера ${ }^{1}$, https://orcid.org/0000-0002-5264-070X

П.Г. Пігулевський ${ }^{\mathbf{1}}$, https://orcid.org/0000-0001-6163-4486

Ю.А. Андрущенко ${ }^{2}$, https://orcid.org/0000-0001-8993-0113

${ }^{1}$ Інститут геофізики ім. С.І. Субботіна НАН України, Київ

2 Головний центр спеціального контролю ДКА України, смт Городок, Житомирська обл.

E-mail:pigulev@ua.fm

\title{
Особливості сейсмічності території Кривбасу
}

Представлено членом-кореспондентом НАН України О.В. Кендзерою

Наведено результати обробки і узагальнення сейсмічних подій на території Криворізького залізорудного басейну (Кривбасу) за період з 2011 по 2020 рр. За результатами аналізу зареєстрованих записів та спектрограм сейсмічних подій цифровими станціями Головного центру спеціального контролю Державного космічного агентства України і сейсмічних станцій Інституту геофізики ім. С.І. Субботіна НАН України встановлено, що основна маса місцевих сейсмічних подій представлена потужними промисловими вибухами в кар'єрах та шахтах. За період 2011-2020 рр. українськими сейсмостанціями зафіксовано понад тисячу потужних промислових вибухів з магнітудою $\geqslant 1,0$. При цьому магнітуда 11 найбільш потужних вибухів, проведених в 2011-2020 рр. у кар'єрах і шахтах, знаходиться в інтервалі значень 2,7-3,5. За цей же проміжок часу в районі Кривбасу зареєстровано 19 сейсмічних подій тектонічного походження $3 m_{b}=2,1 \div 4,5$.

Ключові слова: сейсмічна подія, промисловий вибух, тектоніка, геодинамічна рівновага, природний (локальний) землетрус.

Територія Криворізького залізорудного басейну з середини XIX ст. активно розроблюється. Найбільша інтенсивність видобування руди припадала на 80-90-ті рр. минулого століття. Основним інструментом під час добування залізної руди є потужні вибухові роботи, які виконуються в кар’єрах і шахтах. Вони впливають на пружно-деформаційний стан масиву гірських порід Кривбасу і провокують техногенні і природні сейсмічні події. Локальні сейсмічні події, що відбуваються в тектонічно ослаблених зонах Центральної України з високим рівнем техногенного навантаження, мають здебільшого незначну магнітуду. До таких “проблемних” районів належить Кривбас.

У районі м. Кривий Ріг протягом останніх двох десятків років спостерігалися сейсмічні прояви з магнітудою понад 2,7. Аналіз кількості сейсмічних подій (потужних вибухів) у Кривбасі з 2011 по 2020 рр., які фіксувалися на значній відстані, показує реакцію природ-

Ц и т у в ан н я: Кендзера О.В., Пігулевський П.Г., Андрущенко Ю.А. Особливості сейсмічності території Кривбасу. Допов. Наи. акад. наук Укр. 2021. № 6. С. 87-96. https://doi.org/10.15407/dopovidi2021.06.087 
ного середовища на збільшення їх кількості та потужності. 32018 р., коли кількість спостережених сейсмічних подій збільшилася в декілька разів, почала зростати і кількість природних землетрусів, які відбувалися зі спусковим (тригерним) запізненням. Явище було зафіксовано в 2019 р. Воно збігалося в часі і просторі з максимальною кількістю потужних вибухів у кар’єрах і шахтах.

Про характеристики сейсмічних подій у районі Кривбасу. Дані про сейсмічні події високого рівня $\left(m_{b}=3,7 \div 4,5\right)$, які відбувалися в цьому районі, наведено в каталогах землетрусів Національного центру сейсмологічних даних (м. Харків) за 2000-2013 рр. та в щодекадних станційних бюлетенях і наукових звітах за 2014-2020рр. Головного центру спеціального контролю (ГЦСК) ДКА України і Національного центру сейсмологічних даних Інституту геофізики ім. С.І. Субботіна (ІГФ) НАН України.

Кількість сейсмічних подій (потужних вибухів) у Кривбасі з 2011 по 2020 рр. наведено в таблиці. Переломним моментом у вибухових роботах в кар'єрах і шахтах є 2018 р., коли їх кількість та потужність збільшилася в декілька разів. За останні десять років видобутку руди в Кривбасі на близьких сейсмічних станціях та навіть на значних епіцентральних відстанях від басейну було зафіксовано 1009 сейсмічних подій. Порівняння форм запису і спектрограм землетрусів та вибухів у кар’єрах і шахтах за період 2011-2020 рр. дало підставу з високим ступенем вірогідності віднести до локальних землетрусів різної природи 19 сейсмічних подій у межах Кривбасу. Вісім з виокремлених землетрусів відбулися в піз-

Дати та параметри землетрусів у Кривбасі за період 2011-2020 рр.

\begin{tabular}{|c|c|c|c|c|c|c|}
\hline \multirow{2}{*}{$\begin{array}{l}\text { № } \\
\text { ЗП }\end{array}$} & \multirow{2}{*}{ Дата } & \multirow{2}{*}{ Час (год:хв:с) } & \multicolumn{3}{|c|}{ Координати гіпоцентра } & \multirow{2}{*}{$\begin{array}{c}\text { Магнітуда } \\
\left(m_{b}\right)\end{array}$} \\
\hline & & & $\lambda,{ }^{\circ} \mathrm{E}$ & $\varphi,{ }^{\circ} \mathrm{N}$ & $h$, км & \\
\hline 1 & 14 січня 2011 & $5: 03: 12$ & 33,4 & 48,1 & 5 & 3,5 \\
\hline 2 & 28 листопада 2012 & $20: 47: 43$ & 33,5 & 48,1 & 2 & 3,1 \\
\hline 3 & 4 січня 2013 & $9: 00: 08$ & 33,26 & 47,7 & 5 & 3,1 \\
\hline 4 & 23 червня 2013 & $21: 16: 33$ & 33,5 & 48,08 & 10 & 4,5 \\
\hline 5 & 5 грудня 2016 & $1: 51: 29$ & 33,25 & 47,82 & 5 & 2,7 \\
\hline 6 & 18 січня 2017 & $4: 55: 46$ & 33,49 & 48,04 & 2 & 2,6 \\
\hline 7 & 29 липень 2017 & $3: 31: 02$ & 33,53 & 48,01 & 3,5 & 4,1 \\
\hline 8 & 13 листопада 2017 & $11: 59: 35$ & 33,43 & 48,11 & 33 & 2,1 \\
\hline 9 & 19 лютий 2018 & $0: 35: 03$ & 33,45 & 47,86 & 7 & 2,4 \\
\hline 10 & 29 червня 2018 & $14: 44: 29$ & 33,49 & 48,05 & 7 & 3,4 \\
\hline 11 & 30 червня 2018 & $4: 00: 47$ & 33,41 & 48,04 & 10 & 2,9 \\
\hline 12 & 24 травня 2019 & $4: 00: 04$ & 33,49 & 48,04 & 7 & 2,4 \\
\hline 13 & 9 листопада 2019 & $19: 19: 05$ & 33,49 & 48,05 & 2 & 2,7 \\
\hline 14 & 10 листопада 2019 & $20: 19: 25$ & 33,46 & 48,03 & 2 & 2,7 \\
\hline 15 & 10 листопада 2019 & $22: 00: 44$ & 33,51 & 48,08 & 2 & 2,9 \\
\hline 16 & 7 грудня 2019 & $5: 00: 38$ & 33,47 & 48,04 & 2 & 2,7 \\
\hline 17 & 28 грудня 2019 & $5: 03: 00$ & 33,48 & 48,06 & 2 & 2,6 \\
\hline 18 & 12 червня 2020 & $4: 00: 10$ & 33,46 & 48,03 & 2 & 2,1 \\
\hline 19 & 30 вересня 2020 & $19: 59: 45$ & 33,36 & 48,14 & 5 & 2,9 \\
\hline
\end{tabular}

Примітка. Курсивом виділено землетруси, що відбулися в пізній або нічний час. 
ній або нічний час, коли промислові вибухи заборонені. Дані про зареєстровані місцеві землетруси наведено в таблиці і на рис. 1. Значення магнітуди землетрусів визначено за результатами розрахунків, зроблених з використанням записів, одержаних на станціях ГЦСК ДКА України.

Методика виділення землетрусів. Проведений аналіз наукових джерел показує, що є ознаки у відмінності сейсмічних подій різної природи на основі порівняння форми запису і спектрограм землетрусів та вибухів у кар'єрах і шахтах у районі м. Кривий Ріг. Потужні вибухи в шахтах, коли значення магнітуди $m_{b}$ перевищувало 3,0, проводилися на глибині від 475 до 1300 м. Технологія робіт для зниження сейсмічного ефекту місця розташування вибухової речовини передбачає розподіл їх по площі і в часі. Вибухи повинні відбуватися із затримкою в часі, що гарантує мінімізацію сейсмічного ефекту. В результаті амплітуда $P$-хвилі сумарного сигналу ставала меншою, а її кода - більш ускладненою і розтягнутою, ніж у випадку поодинокого вибуху тієї ж потужності. Форма сигналу в ряді випадків схожа на запис землетрусів, але через інтерференцію коливань спектр сигналу стає іншим [1-3].

На записах вибухів у шахтах переважають поверхневі хвилі, їх амплітуди значно вищі за амплітуди об'ємних хвиль [4]. Максимум спектральної щільності в інтервалі запису $L g$-хвилі спостерігається в діапазоні частот $1-15$ Гц, $L_{R}$-хвилі - у смузі до 1 Гц. Основна частина енергії від вибухових джерел проявляється в інтервалі запису поверхневих хвиль. Складність ідентифікації природи сейсмічних подій пов'язана 3 тим, що основний сейсмічний ефект створюють не самі вибухи в шахті, а їх наслідки - подрібнення та зрушення гірських порід або просідання грунту, в тому числі із зміною рівня земної поверхні.

Встановлено [1-3], що спектрограми сейсмічних подій різного походження, навіть у разі однакового рівня магнітуди, відрізняються. Спектрограми землетрусів порівняно зі спектрограмами вибухів більш насичені, без наявних згасань; чіткі максимуми спектральної щільності зафіксовано в інтервалі запису $L g$ - і $L_{R}$-хвиль. Пов'язане з вибухами збільшення спектральної щільності на спектрограмах відзначено в смузі запису $P$ - і $L g$-хвиль, далі на записі спостерігається їі різке згасання.

Результати аналізу землетрусу 23 червня 2013 р., який став найпотужнішим у районі Кривбасу за останні 30 років [3, 5, 6]. Є припущення що час доби, коли була зареєстрована сейсмічна подія, вказує на тектонічну природу іiі походження: 1) землетрус відбувся вночі - о 21 год 16 хв 33 с (UMC) або 00 год 16 хв (24 червня) за Київським часом; 2) у Державній службі гірничого нагляду та промислової безпеки України заперечували факт проведення будь-яких вибухових робіт на підприємствах Кривого Рогу в такий час доби; 3) за даними різних сейсмологічних центрів значення магнітуди цього землетрусу знаходиться в межах 4,5-4,7 (див. таблицю), тоді як за даними інших станцій магнітуда була значно нижчою - 3,0-4,0; 4) під час вивчення хвильової картини землетрусу 23 червня 2013 р. на записі станції “Малин” виділено час реєстрації вступу хвилі $p P$, згідно з яким встановлено, що осередок цієї події знаходиться на глибині 10 км [3, 5, 6], що є характерним для корових землетрусів.

Встановлено, що географічні координати землетрусу 23 червня 2013 р. майже не відрізняються від координат шахт ім. Леніна та ім. Орджонікідзе - по широті (ф) лише на $0,02^{\circ}$, по довготі $(\lambda)$ - на $0,03^{\circ}$, а по відношенню до координат шахти “Гвардійська” різниця становить відповідно: $0,04^{\circ}$ та $0,02^{\circ}[3,6]$. Дещо більші розбіжності визначені за резуль- 


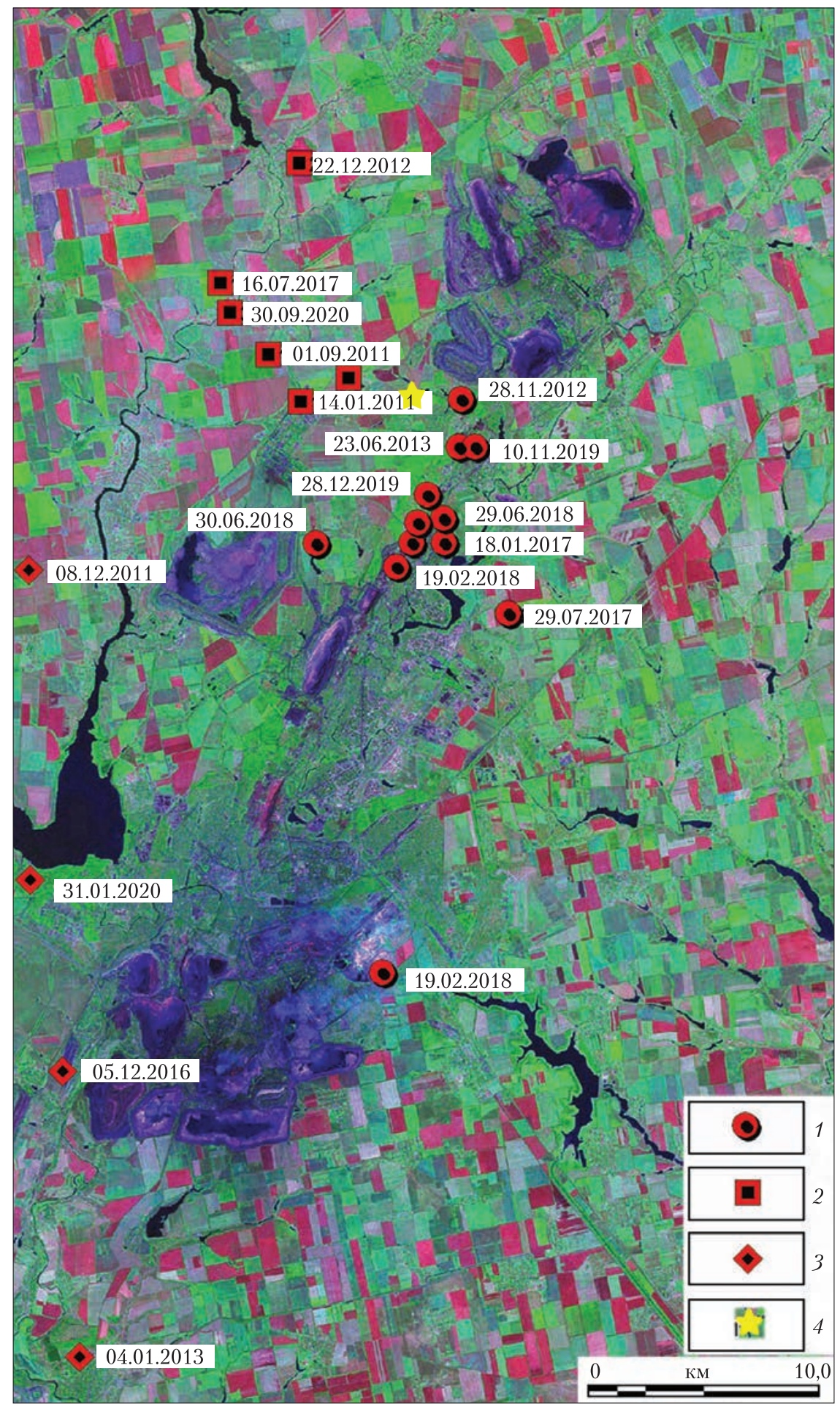

$\boldsymbol{P u c . 1 . ~ Р о з т а ш у в а н н я ~ в ~ р а и ̆ о н і ~ К р и в б а с у ~ е п і ц е н т р і в ~ з е м л е т р у с і в ~ і ~ с е и ̆ с м о л о г і ч н о і ̈ ~ с т а н ц і і ̈ ~ “ К р и в и и ̆ ~ Р і г ” ~}$ на космічному знімку Landsat-6. Умовні позначення: 1 - потужні сейсмічні події в зоні видобування корисних копалин; 2 - потужні сейсмічні події на північному заході від зони видобування корисних копалин; 3 - імовірна лінійна тектонічна зона сучасної активізації; 4 - положення НГ-8 
татами порівняння координат попередніх землетрусів у районі Кривого Рогу відносно шахтних полів. Різниця координат землетрусу 25 грудня 2007 р. була в межах 0,03-0,05 по широті та 0,05-0,06 по довготі, а землетрусу 14 січня 2011 р. - у тих же межах по широті та ще більших по довготі $-0,19-0,21^{\circ}$.

Відзначимо, що перед землетрусом 23 червня 2013 р. вибухів $3 m_{b} \geqslant 3,0$ не зареєстровано; того року магнітуда двох найбільш потужних землетрусів не перевищила значення 2,4. Оскільки для трьох землетрусів (за даними різних, у тому числі зарубіжних сейсмологічних центрів) середні значення глибини вогнища відповідають інтервалу 11,6-20 км, було зроблене таке припущення. У районі м. Кривий Ріг середовище верхнього шару земної кори на глибині до 20 км знаходиться в нестабільному стані, який виник внаслідок потужних промислових вибухів у шахтах, що проводилися протягом довгого періоду часу.

Землетрус 29 липня 2017 р. у районі Кривого Рогу відбувся о 3 год 31хв 02 с (UMC), для аналізу природи сейсмічної події додатково був використаний метод сепарування промислових і ядерних вибухів від природних і техногенних землетрусів, який використовується міжнародною системою сейсмічних спостережень за нерозповсюдженням ядерної зброї $[7,8]$. Застосований метод відокремлення природних землетрусів від вибухів базується на порівняльному аналізі форм запису поточного сейсмічного явища із записами від потужних вибухів і локальних природних землетрусів [8].

Результати порівняльного аналізу записів на станції MIU, розташованій безпосередньо на території Кривого Рогу, і на станції PDU0, розташованій на території Запорізької AEC, свідчать про те, що в Кривому Розі відбувся природний землетрус, а не сильний промисловий вибух потужністю 10-12 кт. Цей висновок грунтується на таких ознаках:

1) наявність двох фаз $P_{n}$ та $P_{g}$ на першій частині запису;

2) наявність двох фаз $\mathrm{S}_{\mathrm{n}}$ та $\mathrm{S}_{\mathrm{g}}$ на другій частині запису, які відсутні на записах вибухів;

3) наявність двох фаз LQ та LR після фаз $\mathrm{S}_{\mathrm{n}}$ та $\mathrm{S}_{\mathrm{g}}$;

4) на записах вибухів немає фази LQ, присутня тільки фаза LR;

Відповідно до однієї з ознак природного землетрусу на його записах спостерігається типовий змінний за амплітудою розподіл енергії сейсмічних хвиль у різних азимутальних квадрантах, у яких почергово домінує $P$ - або $S$ - хвиля; на записах спостерігається поверхнева хвиля Лява LQ, нетипова для запису вибухів.

Визначення просторових параметрів джерела землетрусу 29 липня 2017 р. було проведено методом статистичної обробки результатів з використанням записів події на восьми найближчих сейсмічних станціях України та Молдови. Аналіз результатів показав, що джерело землетрусу розташовується в інтервалі глибин від 3,0 до 3,5 км, що нижче існуючих глибин розробки родовищ багатих залізних руд у шахтах.

Просторове положення обчислених джерел різних землетрусів у районі Кривбасу показано на космічному знімку Landsat-6 (див. рис. 1) і геолого-формаційній карті (рис. 2). У цілому виділяються три зони їх концентрації: перша - потужні сейсмічні події в зоні видобування корисних копалин; друга - потужні сейсмічні події на північному заході від зони видобування корисних копалин; третя - ймовірна лінійна тектонічна зона північнозахідного простягання з проявами сучасної тектонічної активізації.

Тектонічні особливості структури земної кори Кривбасу. Криворізька залізорудна структура розташована в східній частині Західно-Інгулецько-Криворізько-Кременчуцької 

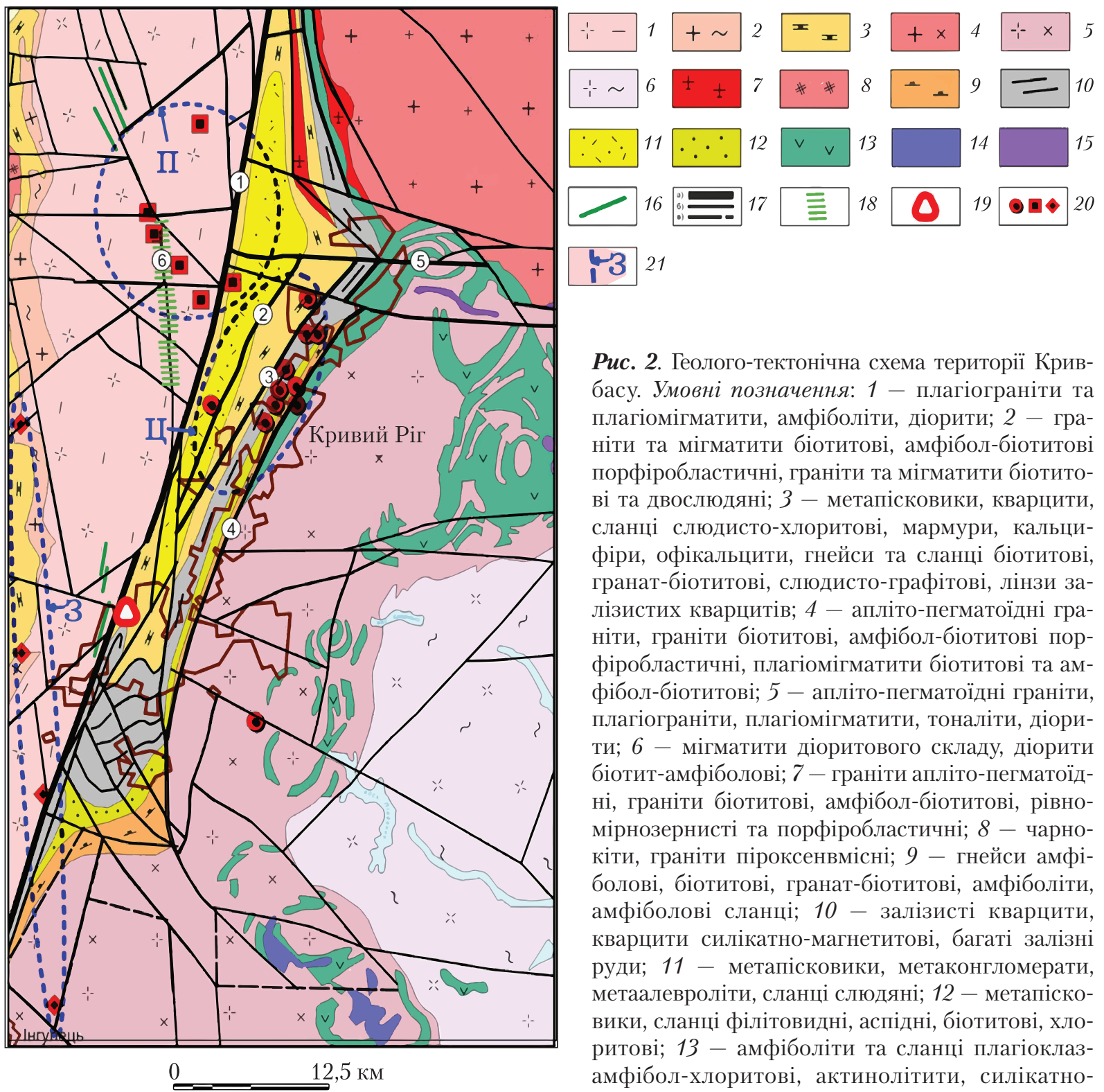

Puc. 2. Геолого-тектонічна схема території Кривбасу. Умовні позначення: 1 - плагіограніти та плагіомігматити, амфіболіти, діорити; 2 - граніти та мігматити біотитові, амфібол-біотитові порфіробластичні, граніти та мігматити біотитові та двослюдяні; 3 - метапісковики, кварцити, сланці слюдисто-хлоритові, мармури, кальцифіри, офікальцити, гнейси та сланці біотитові, гранат-біотитові, слюдисто-графітові, лінзи залізистих кварцитів; 4 - апліто-пегматоїдні граніти, граніти біотитові, амфібол-біотитові порфіробластичні, плагіомігматити біотитові та амфібол-біотитові; 5 - апліто-пегматоїдні граніти, плагіограніти, плагіомігматити, тоналіти, діорити; 6 - мігматити діоритового складу, діорити біотит-амфіболові; 7 - граніти апліто-пегматоїдні, граніти біотитові, амфібол-біотитові, рівномірнозернисті та порфіробластичні; 8 - чарнокіти, граніти піроксенвмісні; 9 - гнейси амфіболові, біотитові, гранат-біотитові, амфіболіти, амфіболові сланці; 10 - залізисті кварцити, кварцити силікатно-магнетитові, багаті залізні руди; 11 - метапісковики, метаконгломерати, метаалевроліти, сланці слюдяні; 12 - метапісковики, сланці філітовидні, аспідні, біотитові, хлоритові; 13 - амфіболіти та сланці плагіоклазамфібол-хлоритові, актинолітити, силікатномагнетитові кварцити; 14 - габро, габро-діабази, перидотити; 15 - габро, габро-норити, перидотити; 16 - діабази, габро-діабази; 17 - розривні порушення різних рангів; 18 - тектоно-метасоматична зона; 19 - сейсмічна станція Кривий Ріг; 20 - сейсмічна подія (землетрус); 21 - зони сейсмічності. Зони групування сейсмічності: П - північна; Ц - центральна; 3 - західна. Цифрами в кружечках позначені глибинні розломи: 1 - Криворізько-Кременчуцький (Західний); 2 - Тарапаківський; 3 - Саксаганський; 4 - Східний; 5 - Девладівський; 6 - Іскрівська тектоно-метасоматична зона.

шовної зони. Вона складається з трьох структурно-формаційних зон [9-11]: Західно-Інгулецької (Кіровоградської), яка прилягає зі сходу до Інгульського мегаблока; ІнгулецькоКриворізької, розташованої між Криворізько-Кременчуцьким і Інгулецьким розломами; Криворізько-Кременчуцької зони (див. рис. 2), яка на теперішній час є джерелом сучас- 
ної сейсмічності в центральної частині УЩ. Криворізько-Кременчуцький глибинний розлом в межах Кривбасу має другу назву - Західний розлом [11]. До Криворізько-Кременчуцької зони розломів приурочена однойменна структурно-формаційна зона, яка перетинає УЩ в меридіональному напрямку і має довжину 275 км та ширину 7 км. Вона достатньо добре вивчена завдяки розробці найбільших у Свропі докембрійських залізорудних басейнів (Криворізького та Кременчуцького).

Криворізько-Кременчуцький глибинний розлом майже на всьому своєму простяганні добре фіксується даними магнітотелуричного зондування як субвертикальний провідник, який відділяє низькоомні утворення Інгулецько-Криворізької структурно-формаційної зони від високоомних (до 10000 Ом · м більше) Середньопридніпровського мегаблока.

За результатами спостережень методом спільної глибинної точки (сейсмічний профіль 02-88 СГТ, розташований на південь від м. Кривий Ріг) простежується західне падіння розлому. Він трасується через всю кору по зміщенню відбиваючих елементів [12]. Його кути падіння змінюються від 75-80 біля поверхні фундаменту з різким виположенням у низах кори до 45-55․ Також у земній корі простежені крупні майже ортогональні і оперяючі (зсувні) до нього тектонічні порушення, які виділені за різкими зміщеннями сейсмічних горизонтів, змінами речовинного складу кори та іншими ознаками.

Про природу землетрусів. Візуальний аналіз розташування землетрусів (див. рис. 1,2 ) дає підставу виділити (локалізувати) три зони сейсмічності. Північна зона пов’язана ділянкою перетину діагональних розломів північно-західного простягання із зоною Криворізько-Кременчуцького розлому, близького до субмеридіонального напрямку, та з Девладівською субширотною зоною. За детальнішого аналізу цієї зони в ній виділяється і окрема лінійна зона північно-західного простягання з азимутом 300-310. Друга зона - центральна, розташовується в області активного видобування залізної руди шахтним і кар’єрним способами. Третя - лінійна зона з азимутом простягання 330-340. Ïї активізація розпочалася досить недавно (з кінця 2011 р.) і вона не тяжіє до території видобування корисних копалин. Найближча сейсмічна подія до території активного видобування залізистих кварцитів відбулася 5 грудня 2016 о 1:51:29 (UMC), тобто в нічний час, що вказує на iㅣ природне походження.

У межах виділеної північної зони розташована Криворізька надглибока свердловина НГ-8 [13], яка показала складну будову зони перетину діагональних розломів північно-західного простягання із зонами Криворізько-Кременчуцького та Девладівського глибинних розломів. У головному стволі свердловини встановлено 26 тектонічних зон завширшки від 5 до 15 см. В інтервалі глибин 3612-3630 та 3816-3850 м [13] під час іiі буріння виникали аварії, які пов’язують із наявністю потужних тектонічних зон - систем різноорієнтованих тріщин. Більшість зон руйнування порід знаходилася в інтервалі глибин 3600-3850 м, у межах якого відкриті тріщини складають 40 \%. На більших глибинах (до 5380 м) були виявлені зони інтенсивного катаклазу - подрібнення і напруженого стану геологічного середовища, який геологи пов'язують з перетином Тарапаківського насуву та Девладівської субширотної зони. На цих глибинах відзначено інтенсивне утворення пустот (до 8-12 см), які неодноразово спричиняли обрушення ствола свердловини.

Характер просторового положення розломів свідчить про правосторонній зсув усієї Криворізької тектонічної системи в цілому. 
Висновки. Локальні сейсмічні події, що відбуваються в тектонічно ослаблених зонах центральної України з високим рівнем техногенного навантаження, мають здебільшого незначну магнітуду. Форма записів та спектрограми локальних землетрусів і промислових вибухів у кар'єрах та шахтах у межах Кривбасу, зареєстрованих станціями ГЦСК ДКА України і СЦ ІГФ НАН України, мають істотні відмінності.

Вплив вибухових робіт на прояв окремих землетрусів обгрунтовується збігом часу реєстрації з часом проведення потужних вибухів у шахтах.

Землетруси в м. Кривий Ріг, під час яких інтенсивність струшування земної поверхні в епіцентрі становила 6 балів за шкалою MSK-64, відбулися 23 червня 2013 р. $\left(m_{b}=4,5\right)$ і 29 липня 2017 р. $\left(m_{b}=4,1\right)$. Виникнення вогнищ цих землетрусів у районі КриворізькоКременчуцької зони розломів, імовірно, $є$ наслідком зміни тектонічних напружень на деяких ділянках земної кори у зв’язку з порушенням геодинамічної рівноваги $[5,10,14]$, спричиненої потужними вибухами під час наземної і підземної розробки корисних копалин.

3 урахуванням викладеного можна класифікувати землетруси як природні спровоковані та підсилені зміною геодинамічної рівноваги масиву гірських порід. Вплив вибухових робіт на прояв окремих землетрусів обгрунтовується збігом часу реєстрації з часом проведення потужних вибухів у шахтах.

Переважне тяжіння координат епіцентрів землетрусу в північній частині Криворізької структури (центральна зона) і їх близькість до зони Тарапаківського і Саксаганського розломів, які контролюють положення родовищ багатих залізних руд, дають підстави припустити, що вона знаходиться в критичному напружено-деформованому стані. Основною його причиною є розробка родовищ багатих руд на великих глибинах, переміщення величезних мас (кар'єр, шахта-відвал, хвостосховище) у просторі та часі і комплекс інших природно-техногенних умов, які порушують рівновагу геологічного середовища.

У південній частині Кривбасу відмічається досить стабільний стан геологічного середовища верхнього шару земної кори. Ймовірно, це пов'язано з іншим характером видобутку корисних копалин і більш спокійними геодинамічними процесами в цій частині Кривбасу. Але останні сейсмічні події вказують на можливе підсилення неотектонічних процесів, що виникають у зоні розломів земної кори у зв'язку з процесом порушення геодинамічної рівноваги під час видобутку корисних копалин і зміщення епіцентрів землетрусів у південну частину Кривбасу.

Глибина джерел землетрусів 2011-2020 pр. переважно становить 5-10 км і характеризує нестабільний стан геологічного середовища верхнього шару земної кори. Сейсмічні події руйнівного характеру тектонічного і техногенного походження створюють небезпеку для життя населення. Не виключено, що в цьому районі у разі подальшого продовження масштабних розробок корисних копалин із застосуванням потужних зарядів під час вибухових робіт можуть відбуватися землетруси з магнітудою понад 4,5.

На сьогодні регулярні сейсмічні спостереження проводяться по одній станції, розташованій на заході м. Кривий Ріг, а задля визначення точних параметрів сейсмічної події насамперед необхідно мати сейсмічну мережу з не менш як чотирьох сейсмічних станцій. 


\section{ЦИТОВАНА ЛІТЕРАТУРА}

1. Андрущенко Ю.А., Кутас В.В., Кендзера А.В., Омельченко В.Д. Слабые землетрясения и промышленные взрывы, зарегистрированные на Восточно-Европейской платформе в пределах территории Украины в 2005-2010 гг. Геофиз. журн. 2012. 34, № 3. С. 49-60.

2. Андрущенко Ю.А., Кутас В.В., Кендзера А.В., Омельченко В.Д., Калитова И.А. Локальные землетрясения на Ураинском щите. Геофиз. журн. 2013. 35, № 6. С. 114-127.

3. Кендзера О.В., Кутас В.В., Андрущенко Ю.А., Пігулевський П.Г., Лісовий Ю.В. Сейсмічність центральної частини Українського щита у період з 2007 по 2013 роки. Геодинамика. 2014. Вип. 16, № 1. C. 144-158. https://doi.org/10.23939/jpd2014.01.144

4. Здещиц В.М., Калініченко О.А., Пігулевський П.Г., Рибалко Б.І., Щербіна С.В. Дослідження мікросейсмічних явищ техногенного походження. Геофіз. журн. 2015. 37, № 5. С. 132-142.

5. Габсатарова И.П., Кендзера А.В., Надежка Л.И., Пигулевский П.И., Бабкова Е.А., Коломиец М.В., Пивоваров С.П. Новое сейсмическое событие в Криворожье и механизм его очага. Вестн. ВГУ. Сер. Геол. 2013. № 2. С. 134-140.

6. Пигулевский П.И., Свистун В.К., Щербина С.В. О сейсмическом событии в Кривбассе (Украина) и механизме его очага. Вестн. ВГУ. Сер. Геол. 2015. № 1. С. 102-108.

7. Пігулевський П.Г., Кендзера О.В., Щербіна С.В., Вербицький С.Т., Шумлянська Л.А., Калініченко О.О., Гурова І.Ю., Ільєнко В.А., Амашукелі Т.А., Чалий О.О. Природа криворізького землетрусу 29 липня 2017 року. Геол.-мінерал. вісн. Криворіз. нач. ун-ту. 2017. № 1. С. 92-104.

8. Walter W.R., Matzel E., Pasyanos M.E., Harris D.B., Gok R., Ford S.R. Empirical observations of earthquake-explosion discrimination using $\mathrm{P} / \mathrm{S}$ ratios and implications for the sources of explosion $\mathrm{S}$-waves. Ground-based nuclear explosion monitoring technologies: Proceedings of the 29th Monitoring research review (Denver, Colorado, 25-27 Sept. 2007). Denver, 2007. P. 684-693.

9. Азаров Н.Я., Анциферов, А.В., Шеремет Е.М., Глевасский Е.Б., Есипчук К.Е., Кулик С.Н., Бурахович Т.К., Пигулевский П.И., Николаев Ю.И., Николаев И.Ю., Сетая С.Д., Захаров В.В., Курлов Н.К. Геолого-геофизическая модель Криворожско-Кременчугской шовной зоны Украинского щита. Киев: Наук. думка, 2006. 196 с.

10. Пигулевский П.И., Свистун В.К., Щербина С.В. О тектоническом строении, геодинамических и сейсмологических особенностях Кривбасса. Екологія і природокористування. 2013. Вип. 17. С. 37-46.

11. Пігулевський П.Г., Свистун В.К., Мечніков Ю.П., Кирилюк О.С., Лісовий Ю.В. Особливості диз’юнктивної тектоніки Криворізького залізорудного району. Геофиз. журн. 2016. 38, № 5. С. 154-163.

12. Бородулин В.А., Байсарович М.Н. Модель литосферы Украинского щита по материалам ОГТ. Геофиз. журн. 1992. 14, № 4. С. 57-66.

13. Криворожская сверхглубокая скважина СГ-8: Шеремет Е.М. (Ред.). Донецк: “Ноулидж”, 2011. 555 с.

14. Пигулевский П.И. О современной активизации докембрийских глубинных разломов Украинского щита. 3б. наук. пращь НГУ. 2015. № 46. С. 38-44.

Надійшло до редакції 27.07.2021

\section{REFERENCES}

1. Andrushchenko, Yu. A., Kutas, V. V., Kendzera, A. V. \& Omelchenko, V. D. (2012). Weak earthquakes and industrial explosions recorded in the East European Platform within the territory of Ukraine in 2005-2010. Geophys. J., 34, No. 3, pp. 49-60 (in Russian).

2. Andrushchenko, Yu. A., Kutas, V. V., Kendzera, A. V., Omelchenko, V. D. \& Kalitova, I. A. (2013). Local earthquakes on the Ukrainian shield. Geophys. J., 35, No. 6, pp. 114-127 (in Russian).

3. Kendzera, O. V., Kutas, V. V., Andrushchenko, Yu. A., Pigulevskiy, P. G. \& Lisovy, Yu. V. (2014). Seismicity of central part of Ukrainian Shield in 2007-2013 period. Geodynamics, Iss. 16, No. 1. pp. 144-158 (in Ukrainian). https://doi.org/10.23939/jpd2014.01.144

4. Zdeshchyts, V. M., Kalinichenko, O. A., Pigulevskyi, P. I., Rybalko, B. I. \& Shcherbina, S. V. (2015). Investigation of micro-seismic phenomena of anthropogenic origin. Geophys. J., 37, No. 5. pp. 132-142 (in Ukrainian). 
5. Gabsatarova, I. P., Kendzera, A. V., Nadezhka, L. I., Pigulevskiy, P. I., Bobkova, E. A., Kolomiets, M. V. \& Pivovarov, S. P. (2013). New seismic event in Kryvyi Rih and the mechanism of its source. Vestn. VGU. Ser. Geol., No. 2. pp. 134-140 (in Russian).

6. Pigulevskiy, P. I., Svistun, V. K. \& Shcherbina, S. V. (2015). About seismic event in Krivbass (Ukraine) and the mechanism of its center. Vestn. VGU. Ser. Geol., No. 1. pp. 102-108 (in Russian).

7. Pigulevskyi, P. H., Kendzera, O. V., Shcherbina, S. V., Verbytskyi, S. T., Shumlyanska, L. A., Kalinichenko, O. O., Gurova, I. Yu., Il'yenko, V. A., Amashukeli, T. A. \& Chalyi, O. O. (2017). Nature of Krivyi Rih earthquake on July 29, 2017. Heoloho-mineralohichnyy visnyk Kryvoriz'koho natsional'noho universytetu, No. 1, pp. 92-104 (in Ukrainian).

8. Walter, W. R., Matzel, E., Pasyanos, M. E., Harris, D. B., Gok, R. \& Ford, S. R. (2007, September). Empirical observations of earthquake-explosion discrimination using $\mathrm{P} / \mathrm{S}$ ratios and implications for the sources of explosion S-waves. Proceedings of the 29th Monitoring research review "Ground-based nuclear explosion monitoring technologies", (pp. 684-693). Denver.

9. Azarov, N. Ya., Antsiferov, A. V., Sheremet, E. M., Glevassky, E. B., Esipchuk, K. E., Kulik, S. N., Burakhovich, T. K., Pigulevskiy, P. I., Nikolaev, Yu. I., Nikolaev, I. Yu., Setaya, S. D., Zakharov, V. V. \& Kurlov, N. K. (2006). Geological and geophysical model of the Krivoy Rog-Kremenchug suture zone of the Ukrainian Shield. Kyiv: Naukova Dumka (in Russian).

10. Pigulevskiy, P. I., Svistun, V. K. \& Shcherbina, S. V. (2013). About tectonic structure, geodynamic and seismological features of Krivoy Rog iron ore basin. Ekolohiya i pryrodokorystuvannya, Iss. 17, pp. 37-46 (in Russian).

11. Pihulevskyy, P. G., Svistun, V. K., Mechnikov, Yu. P., Kyrylyuk, O. S. \& Lisovoy, Yu.V. (2016). Features of disjunctive tectonics of Kryvoi Rog iron ore area. Geophys. J., 38, No. 5, pp.154-163 (in Ukrainian).

12. Borodulin, V. A. \& Baysarovich, M. N. (1992). Model of the lithosphere of the Ukrainian Shield based on CDP materials. Geophys. J., 14, No. 4, pp. 57-66 (in Russian).

13. Sheremet, E. M. (Ed.). (2011). Krivoy Rog superdeep well SG-8. Donetsk: Noulidzh (in Russian).

14. Pigulevsky, P. I. (2015). On the modern activation of the Precambrian deep faults of the Ukrainian shield. Zbirnyk nauk. prats NGU, No. 46, pp. 38-44 (in Russian).

Received 27.07.2021

O.V. Kendzera ${ }^{1}$, https://orcid.org/0000-0002-5264-070X

P.G. Pigulevskiy ${ }^{1}$, https://orcid.org/0000-0001-6163-4486

Yu.A. Andrushchenko², https://orcid.org/0000-0001-8993-0113

${ }^{1}$ S.I. Subbotin Institute of Geophysics of the NAS of Ukraine, Kyiv

2 Main Center for Special Monitoring of the State Space Agency of Ukraine, Gorodok, Zhitomir region E-mail: pigulev@ua.fm

\section{FEATURES OF THE KRIVBAS TERRITORY SEISMICITY}

The results of processing and a generalization of seismic events on the territory of the Kryvyi Rih iron ore basin (Kryvbas) for the period from 2011 till 2020 are presented. By the analysis of the records at stations of I.S. Subbotin Institute of Geophysics of the NAS of Ukraine and the spectrograms of seismic events recorded by digital seismic stations of the General Center of Seismological Controls of the State Center of Space Agency of Ukraine, we found that the most of local seismic events are represented by powerful industrial explosions in quarries and mines. During the period 2011-2020, the Ukrainian seismic stations recorded more than a thousand powerful industrial explosions with $m_{b} \geqslant 1.0$. The magnitude of the 11 most powerful explosions carried out in 2011-2020 in quarries and mines is in the range of 2.7-3.5. During the same period of time, 19 seismic events of the tectonic origin with $m_{b}=2.1 \div 4.5$ were registered in the Kryvbas region.

Keywords: seismic event, industrial explosion, tectonics, geodynamic equilibrium, natural (local) earthquake. 